\title{
Tocotrienol-Rich Fraction Prevents Cell Cycle Arrest and Elongates Telomere Length in Senescent Human Diploid Fibroblasts
}

\author{
Suzana Makpol, ${ }^{1}$ Lina Wati Durani, ${ }^{1}$ Kien Hui Chua, ${ }^{2}$ Yasmin Anum Mohd Yusof, ${ }^{1}$ \\ and Wan Zurinah Wan Ngah ${ }^{1}$ \\ ${ }^{1}$ Department of Biochemistry, Faculty of Medicine, National University of Malaysia, Jalan Raja Muda Abdul Aziz, \\ 50300 Kuala Lumpur, Malaysia \\ ${ }^{2}$ Department of Physiology, Faculty of Medicine, National University of Malaysia, Jalan Raja Muda Abdul Aziz, \\ 50300 Kuala Lumpur, Malaysia
}

Correspondence should be addressed to Suzana Makpol, suzanamakpol@yahoo.com

Received 12 October 2010; Accepted 31 January 2011

Academic Editor: Sarah H. Elsea

Copyright (C) 2011 Suzana Makpol et al. This is an open access article distributed under the Creative Commons Attribution License, which permits unrestricted use, distribution, and reproduction in any medium, provided the original work is properly cited.

This study determined the molecular mechanisms of tocotrienol-rich fraction (TRF) in preventing cellular senescence of human diploid fibroblasts (HDFs). Primary culture of HDFs at various passages were incubated with $0.5 \mathrm{mg} / \mathrm{mL}$ TRF for $24 \mathrm{~h}$. Telomere shortening with decreased telomerase activity was observed in senescent HDFs while the levels of damaged DNA and number of cells in $G_{0} / G_{1}$ phase were increased and $S$ phase cells were decreased. Incubation with TRF reversed the morphology of senescent HDFs to resemble that of young cells with decreased activity of SA- $\beta$-gal, damaged DNA, and cells in $G_{0} / G_{1}$ phase while cells in the $S$ phase were increased. Elongated telomere length and restoration of telomerase activity were observed in TRF-treated senescent HDFs. These findings confirmed the ability of tocotrienol-rich fraction in preventing HDFs cellular ageing by restoring telomere length and telomerase activity, reducing damaged DNA, and reversing cell cycle arrest associated with senescence.

\section{Introduction}

The in vitro ageing of human diploid fibroblasts (HDFs), first described by Hayflick and Moorhead [1], has become a classical experimental model to study cellular ageing. HDFs have a limited ability to divide when cultured in vitro. Normally after about 50 cell divisions, HDFs enter a state of irreversible proliferative arrest, termed as replicative senescence or cellular senescence [1].

Cells with less than 10 passages were considered young cells with high proliferative ability while cultures at 10-20 passages have entered an intermediate state or pre-senescence, and cultures of over 25 passages with no detectable doubling in cell numbers for 2 weeks were considered as senescent cells [2]. Senescent cells have been shown to accumulate with age in human tissues and, thus, have been suggested to contribute to organismal ageing [3].
Reactive oxygen species (ROS) were implicated in replicative senescence and ageing [4]. During physiological metabolism, endogenous ROS which include superoxide anion, hydrogen peroxide, hydroxyl radicals, and singlet oxygen are constantly generated in most cells. High level of ROS can cause damage to proteins, lipids, and DNA [5]. Accumulation of oxidatively damaged cellular macromolecules is suggested to account for the free radical theory of ageing.

Upon entering the state of senescence, cells undergo dramatic changes in morphology. The cell size or volume is increased with accumulation of cellular debris and intracellular vesicles, many of which are lysosomes. It has been reported that senescent fibroblasts became flattened and more irregular in shape [6] with increased expression of senescence marker such as senescence associated $\beta$-galactosidase (SA- $\beta$-gal). Both in vitro and in vivo studies have shown the increase in percentage of cells 
positive for SA- $\beta$-gal with cumulative population doublings (CPDs) and age [7]. Nevertheless, the mechanisms that are responsible for the continuous cell growth and increased in SA- $\beta$-gal expression in senescent cells have not been well elucidated [8].

Ageing cells accumulate DNA damage which may consequently lead to an irreversible growth arrest [9]. Cell cycle checkpoints sense damage of the DNA structure and elicit complex cellular repair response. The checkpoints maintain cell cycle arrest while the repair takes place followed by cell cycle progression once repair is completed. Cells undergo permanent cell cycle arrest and apoptosis if the DNA cannot be repaired adequately. A permanent cell cycle arrest occurs with cells remaining in $G_{0} / G_{1}$ phase during senescence [10].

Besides oxidative DNA damage accumulation, telomere shortening has been widely considered as another important mechanism to trigger replicative senescence in human fibroblasts. Significant telomere shortening occurred as a consequence of prolonged $\mathrm{H}_{2} \mathrm{O}_{2}$ treatment but not in acute treatment [4]. Recently, studies by von Zlignicki et al. [11] showed that telomere shortening was largely dependent on the interplay of oxidative stress and antioxidant defence rather than the cell divisions. A comparison of the telomere shortening rates in different HDFs under different conditions revealed that the ratio between oxidative damage and antioxidative defence was quantitatively the most important determinant of telomere shortening [12]. To prevent progressive DNA loss with subsequent rounds of DNA replication, many cells maintain their telomeres by the action of telomerase, a specialized RNA-protein complex that uses its RNA component as a template for the extension of the telomere by its reverse transcriptase subunit [13].

In the absence of an adequate repair system, accumulated DNA damage caused mutagenic alterations resulting in cancer, ageing, and abnormalities in the nervous system [14]. Accumulating evidence demonstrated that vitamin E, the most potent lipid peroxyl radical scavenger, significantly reduced free radical-induced chromosomal damage [15]. Vitamin $\mathrm{E}$ has been shown to reduce $\mathrm{H}_{2} \mathrm{O}_{2}$-induced $\mathrm{OH}^{\bullet}$ generation and subsequent DNA base pair modification in human oral epithelial cells [16] and $\mathrm{H}_{2} \mathrm{O}_{2}$-induced DNA strand breaks in human skin cell line VH10 [17]. Measurement of DNA repair ability tested in lymphocytes indicated that vitamin $\mathrm{E}$ increased the removal rate of damaged DNA compared to cells that are not treated with vitamin $\mathrm{E}$ [18].

Natural vitamin E comprises of eight different isomers; they are $\alpha_{-}, \beta-, \gamma_{\text {-, }}$ and $\delta$-tocopherols and $\alpha-, \beta-, \gamma$-, and $\delta$-tocotrienols [19]. Based on its lipophilicity, vitamin $\mathrm{E}$ is considered to be the major chain-breaking antioxidant preventing the propagation of oxidative stress, especially in biological membranes [20]. Vitamin E specifically $\alpha$ tocopherol has been reported to be able to modulate signal transduction and gene expression via its antioxidant and non-antioxidant properties [19].

Recently, the different isomers of tocotrienol have gained increasing scientific interest due to their eminent antioxidant effects and a non-antioxidant activity profile that differs from tocopherols [20]. Tocotrienols are found in abundance in rice bran, palm oil, oat, and barley [21]. Tocotrienol-rich fraction consists of $\alpha$-tocopherol and four isomers of tocotrienols $(\alpha, \beta, \gamma$, and $\delta)$, all of which are potent membrane-soluble antioxidants [22].

The differences in the properties of tocotrienol have suggested protective effects in diseases such as cardiovascular disease and cancer in experimental animals [23]. In an animal model of ageing, tocotrienol extended lifespan by $19 \%$ while reducing protein carbonylation, a particularly toxic oxidation process indicative of ageing [24]. Since oxidants contribute to the ageing process and ageing-related diseases in many species, possible protection from ageing by antioxidants such as tocotrienol and tocopherol is suggested.

Even though beneficial effects of vitamin $\mathrm{E}$ have been established in ageing [25], ongoing studies are being done to determine mechanisms involved and actual response of different stages of cellular ageing. In view of this, this study was designed to evaluate the molecular mechanism of tocotrienol-rich fraction in possibly modulating different stages of cellular ageing in HDFs by determining the changes in molecular markers of cell-ageing SA- $\beta$-gal, DNA damage, telomere shortening, and cell cycle progression in young, presenescent, and senescent HDFs.

\section{Materials and Methods}

2.1. Cell Culture and the Induction of Senescence. This research has been approved by the Ethics Committee of National University of Malaysia (Approval Project Code: FF218-2008). Primary HDFs were derived from the foreskins of three 9- to 12-year-old boys after circumcision. Written informed consents were obtained from parents of all subjects. The samples were aseptically collected and washed several times with $75 \%$ alcohol and phosphate buffered saline (PBS) containing $1 \%$ antibiotic-antimycotic solution (PAA, Austria). After removing the epidermis, the pure dermis was cut into small pieces and transferred into a falcon tube containing $0.03 \%$ collagenase type I solution (Worthington Biochemical Corporation, USA). Pure dermis was digested in the incubator shaker at $37^{\circ} \mathrm{C}$ for $6-12 \mathrm{~h}$. Then, cells were rinsed with PBS before being cultured in Dulbecco Modified Eagle Medium (DMEM) containing 10\% fetal bovine serum (FBS) (PAA, Austria) and $1 \%$ antibiotic-antimycotic solution at $37^{\circ} \mathrm{C}$ in $5 \% \mathrm{CO}_{2}$ humidified incubator. After 5-6 days, the cultured HDFs were harvested by trypsinization and cultureexpand into new T25 culture flasks (Nunc, Denmark) with expansion degree of $1: 4$. When the subcultures reached 80 $90 \%$ confluence, serial passaging was done by trypsinization and the number of population doublings (PDs) was monitored until HDFs reached senescence. For subsequent experiments, cells were used at either passage 4 (young cell, population doubling; PD < 12), passage 15 (presenescent cell, $30<\mathrm{PD}<40$ ), and passage 30 (senescent cell, $\mathrm{PD}>55$ ).

2.2. Effects of Various Concentrations of TRF on Cell Viability. Cell viability study was performed using MTS assay. Briefly, stock solutions of TRF Gold Tri E 50 (Golden Hope Bioganic 
Sdn Bhd, Malaysia) was freshly prepared in $100 \%$ ethanol $(1: 1)$ and kept at $-20^{\circ} \mathrm{C}$ for not more than one month. Immediately before use, TRF was incubated with FBS overnight at $37^{\circ} \mathrm{C}$. Serial dilutions of TRF at concentrations of $0.1,0.2,0.3,0.4$, and $0.5 \mathrm{mg} / \mathrm{mL}$ were prepared in culture medium mixed with $50 \%$ ethanol $(1: 1)$. Cells were plated at $2 \times 10^{4}$ in 96-well plate and incubated overnight. Then, the medium was replaced with new medium containing the various concentrations of TRF and incubated for $24 \mathrm{~h}$ at $37^{\circ} \mathrm{C}$, in $5 \% \mathrm{CO}_{2}$. After incubation, $20 \mu \mathrm{L}$ MTS was added and cells were further incubated for $2 \mathrm{~h}$. The absorbance of MTS formazan formed was measured at $490 \mathrm{~nm}$ with a microtiter plate reader (VeraMax Molecular Devices, USA). The viability assay was performed to obtain the optimum dose of TRF treatment for subsequent experiments. In the subsequent experiments, treated HDFs were incubated with $0.5 \mathrm{mg} / \mathrm{mL}$ TRF for $24 \mathrm{~h}$ while untreated cells were cultured in Dulbecco Modified Eagle Medium (DMEM) containing $10 \%$ fetal bovine serum (FBS) (PAA, Austria). The media for the untreated cells was changed in parallel to the treated cells. Both untreated and treated cells were harvested on the same day.

2.3. Morphology Analysis and Senescence-Associated $\beta$-Galactosidase (SA- $\beta$-gal) Staining. HDFs positive for SA- $\beta$-gal activity was determined as described by Dimri et al. [7]. SA- $\beta$-gal staining was performed with a senescent cell staining kit (Sigma, USA) according to the manufacturer's instructions. A total of $1 \times 10^{5}$ cells in the TRF-treated and control groups were seeded in six-well plates and incubated with fixation buffer ( $2 \%$ formaldehyde $/ 0.2 \%$ glutaraldehyde) for $6-7 \mathrm{mins}$ at room temperature. Cells were then rinsed three times with PBS and incubated with 5-bromo-4-chloro3 -indolyl $\beta$-D-galactopyranoside at $1 \mathrm{mg} / \mathrm{mL}$ in a buffer containing $40 \mathrm{mM}$ citric acid/phosphate $(\mathrm{pH} 6.0), 5 \mathrm{mM}$ $\mathrm{K}_{3} \mathrm{FeCN}_{6}, 5 \mathrm{mM} \mathrm{K}_{4} \mathrm{FeCN}_{6}, 150 \mathrm{mM} \mathrm{NaCl}$, and $2 \mathrm{mM} \mathrm{MgCl}_{2}$ for $4 \mathrm{~h}$ at $37^{\circ} \mathrm{C}$ in the absence of $\mathrm{CO}_{2}$. Blue staining was visible after incubation, and the percentage of blue cells observed in 100 cells under a light microscope was calculated.

2.4. Estimation of Telomere Length. Genomic DNA was isolated using Wizard Genomic Purification Kit (Promega, USA). The DNA samples were processed separately for each treatment. Telomere assay was performed using TeloTAGGG Telomere Length Assay kit (Roche, USA) that determined telomere length using terminal restriction fragment principle. Three $\mu \mathrm{g}$ of DNA was digested with 20 units each of Hinf I and RsaI for $2 \mathrm{~h}$ at $37^{\circ} \mathrm{C}$. Complete cutting is confirmed by electrophoresis of the DNA digests on $0.8 \%$ agarose gel. Fractionated DNA fragments were transferred to nylon membranes Hybond- $\mathrm{N}^{+}$(Amersham, UK) by an alkaline transfer technique using capillary blotting. The blotted DNA fragments were hybridized to a digoxigenin (DIG)-labeled probe specific for telomeric repeats (TTAGGG) for $3 \mathrm{~h}$ at $42^{\circ} \mathrm{C}$ with gentle agitation with a DIGspecific antibody covalently coupled to alkaline phosphatase. Finally, the immobilized telomere probe was visualized by alkaline phosphatase metabolizing CDP-Star, a highly sensitive chemiluminescence substrate. The average terminal restriction fragment length was determined by comparing signals relative to a nuclear weight standard on X-ray film. The average terminal restriction fragment length of each sample was obtained by scanning the exposed X-ray film and quantifying using ImageMaster Total lab software.

2.5. Estimation of Telomerase Activity. Detection of telomerase activity using the telomeric repeat amplification protocol (TRAP) in cultured cells involves the addition of TTAGGG repeats by telomerase to an oligonucleotide (TS) and the subsequent PCR amplification of these extension products with both the forward (TS) and reverse (CX) primers. The TRAPeze telomerase detection kit (Chemicon, USA) was used as recommended by the manufacturer with minor modifications [26]. Briefly, cell pellets were stored at $-80^{\circ} \mathrm{C}$ until lysis was performed. The lysis buffer contained $1 \%$ Nonidet P-40 and $0.25 \mathrm{mM}$ sodium deoxycholate to increase the efficiency of extraction. Cells were lysed, then left on ice for $30 \mathrm{~min}$, and centrifuged at $14,000 \mathrm{~g}$ for $20 \mathrm{~min}$ at $4^{\circ} \mathrm{C}$. The supernatant was flash-frozen and stored at $-80^{\circ} \mathrm{C}$. The extracted protein concentration was determined from bovine serum albumin (BSA) standard plot of $\mathrm{OD}_{595}$ versus $\mu \mathrm{g}$ BSA based on Bradford method. For the PCR reaction, $500 \mathrm{ng} / \mu \mathrm{L}$ of protein was needed. The total counts in the sample was added to $48 \mu \mathrm{L}$ reaction mixture and 2 units of Taq DNA polymerase (Promega, USA). After incubation at room temperature for $30 \mathrm{~min}$ for the telomerase extension reaction, samples were heated to $92^{\circ} \mathrm{C}$ for $3 \mathrm{~min}$ to inactivate telomerase followed by PCR amplification. PCR products were electrophoresed on 10\% polyacrylamide gel, and the gel was further analysed and quantitated using the ImageMaster Total lab software. Telomerase activity was calculated as the ratio of the intensity of telomerase ladders to the intensity of the 36-bp internal standard.

2.6. Determination of DNA Damage. DNA damage was assessed using single-cell gel electrophoresis assay (SCGE; Comet assay). The alkaline version of Comet assay was performed according to the method described by Singh et al. [27]. Frosted microscope slides were prepared with $105 \mu \mathrm{L}$ of normal melting agarose. Cells were embedded in $65 \mu \mathrm{L} 0.6 \%$ low-melting point agarose layer (Boehringer Mannheim, Germany) (DNAse free, RNAse free) on agarosecoated frosted slides. The cells were lysed in a buffer containing $2.5 \mathrm{M} \mathrm{NaCl}, 100 \mathrm{mM}$ EDTA, $10 \mathrm{mM}$ Tris, $1 \% \mathrm{~N}$ laurylsarcosine, $1 \%$ Triton, and 2\% dimethylsulphoxide, at $\mathrm{pH} 10$, for $1 \mathrm{~h}$ at $4^{\circ} \mathrm{C}$. Thereafter, the cells were exposed to a strong alkaline solution $(300 \mathrm{mM} \mathrm{NaOH}, 1 \mathrm{mM}$ EDTA, $\mathrm{pH}$ 13) for $25 \mathrm{~min}$ in an electrophoresis chamber. Electrophoresis was performed for $20 \mathrm{~min}$ at $25 \mathrm{~V}$ and $200 \mathrm{~mA}$. The slides were then neutralized $(0.4 \mathrm{M}$ Tris, $\mathrm{pH} 7.5)$ and stained with ethidium bromide $(20 \mu \mathrm{g} / \mathrm{mL})$. Comets were analysed by fluorescence microscopy (Carl Zeiss, Germany) with visual inspection of tail length of nuclei. The cell nuclei were classified into five categories: (0) undamaged (nuclei without comet tail), (1) low damaged (nuclei with comet tails up to two fold longer than nucleus diameter), (2) damaged (nuclei with comet tail two to three-fold longer than nucleus diameter), (3) highly damaged (nuclei with comet tails three 
fold longer than nucleus diameter), and (4) severely damaged (cell nuclei was almost not visible with long and dispersed comet tails). At least 300 cells per slide were counted, and two slides were prepared for each treatment. A total damage score was determined by multiplying the number of cells assigned to each grade of damage by the numeric value of the grade according to methods describe by Heaton et al. [28]. Total DNA damage score was calculated as follows:

$$
\begin{aligned}
\text { Total DNA damage }=[ & \left(0 \times n_{0}\right)+\left(1 \times n_{1}\right)+\left(2 \times n_{2}\right) \\
& \left.+\left(3 \times n_{3}\right)+\left(4 \times n_{4}\right)\right],
\end{aligned}
$$

where $n_{0}=$ cells with score $0, n_{1}=$ cells with score $1, n_{2}=$ cells with score $2, n_{3}=$ cells with score 3 , and $n_{4}=$ cells with score 4.

2.7. Cell Cycle Analysis. Untreated control and TRF-treated HDFs were subcultured in $10 \mathrm{~cm}^{2}$ tissue culture dishes. After $24 \mathrm{~h}$ incubation, cells were harvested and prepared using CycleTEST PLUS DNA Reagent Kit (Becton Dickinson, USA) according to the manufacturer's instruction. Cell cycle status was analyzed by FACS Caliber flow cytometer (Becton Dickinson, USA) using propidium iodide (PI) as a specific fluorescent dye probe. The PI fluorescence intensity of 10,000 cells was measured for each sample.

2.8. Statistical Analysis. Each experiment was carried out in triplicates with at least 3 independent cultures with comparable results. Data are reported as mean \pm SD of at least three experiments. Comparison between groups were made by ANOVA and Student's $t$-test (two-tailed). $P<.05$ was considered statistically significant.

\section{Results}

3.1. Dose Response Curve of TRF in Cultured HDFs. Figure 1 shows the percentage of viable fibroblast cells after incubated with TRF at various concentrations $(0.1-0.5 \mathrm{mg} / \mathrm{mL})$ for $24 \mathrm{~h}$. The percentage of viable cells was significantly increased $(P<.05)$ with TRF treatment at $0.5 \mathrm{mg} / \mathrm{mL}$ (Figure $1(\mathrm{a})$ ) for young HDFs. For presenescent HDFs, the percentage of viable cells was significantly increased $(P<.05)$ with TRF incubation at concentrations of $0.3 \mathrm{mg} / \mathrm{mL}, 0.4 \mathrm{mg} / \mathrm{mL}$, and $0.5 \mathrm{mg} / \mathrm{mL}$ (Figure 1(b)) while the percentage of viable cells for senescent HDFs was significantly increased $(P<.05)$ with TRF treatment at all concentrations (Figure 1(c)). Therefore, $\mathrm{TRF}$ at concentration $0.5 \mu \mathrm{g} / \mathrm{mL}$ was used for the subsequent experiments for all types of HDFs.

3.2. Cell Morphology and SA- $\beta$-Galactosidase Expression. Morphological changes were observed with ageing of the HDFs. Young HDFs displayed the normal spindle shape characteristic of fibroblast cells. However, with senescence, the original fibroblastic shape was lost and HDFs became larger and flattened with accumulation of cytoplasmic granular inclusions (Figures 2(a)-2(c)). The morphology of TRF-treated HDFs resembled that of young cells with more spindle shaped cells present (Figures 2(d)-2(f)).

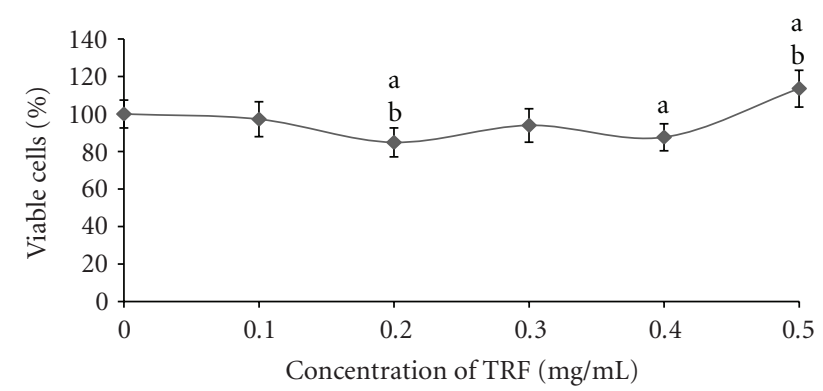

(a)

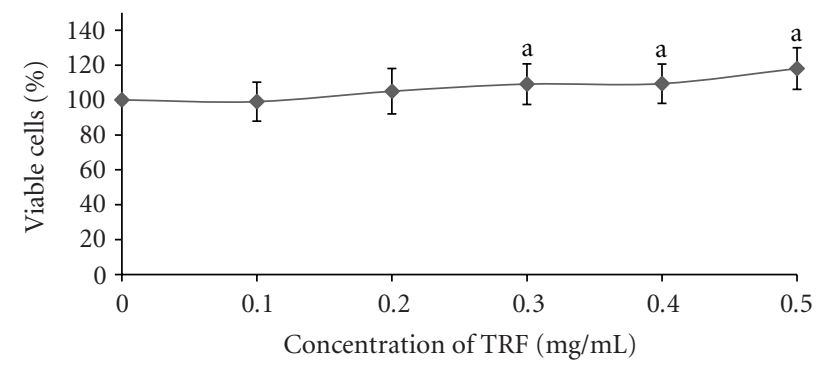

(b)

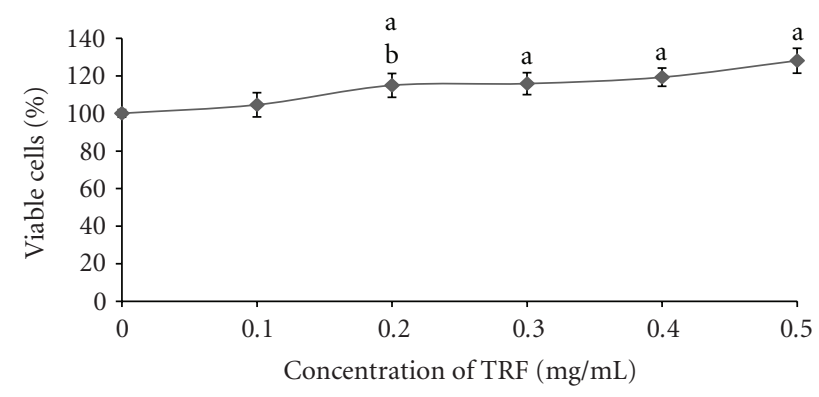

(c)

FIgURE 1: Dose response of tocotrienol-rich fraction (TRF) on young (a), presenescent (b), and senescent (c) HDFs after $24 \mathrm{~h}$ incubation at $37^{\circ} \mathrm{C}$. Incubation with TRF caused a significant increase in the viability of HDFs. ${ }^{a}$ Denotes $P<.05$ compared to control, ${ }^{\mathrm{b}} P<.05$ compared to lower concentration. Data are presented as mean $\pm \mathrm{SD}, n=9$.

Positive blue stain of SA- $\beta$-gal appeared mainly in HDFs at passage 30 suggesting the presence of senescent cells (Figure 3). Quantitative analysis showed the percentage of cells positive for SA- $\beta$-gal staining was increased $(P<.05)$ in senescent cells compared to young and presenescent HDFs. Incubation of senescent cells with $0.5 \mathrm{mg} / \mathrm{mL}$ TRF significantly decreased $(P<.05)$ the percentage of positive SA- $\beta$ gal stained cells compared to untreated control (Figure 4).

\subsection{Effect of TRF Treatment on DNA Damage and Cell Cycle} Progression. Damaged DNA was higher in senescent HDFs compared to young and presenescent cells $(P<.05)$ which was decreased with TRF-treatment $(P<.05)$ (Figure 5). Cell cycle progression analysis showed that the cell population in the $\mathrm{S}$ phase was lower $(P<.05)$ in senescent HDFs compared to young HDFs. Treatment with TRF significantly increased $(P<.05)$ cells in the $S$ phase and $\mathrm{G}_{2} / \mathrm{M}$ phase 


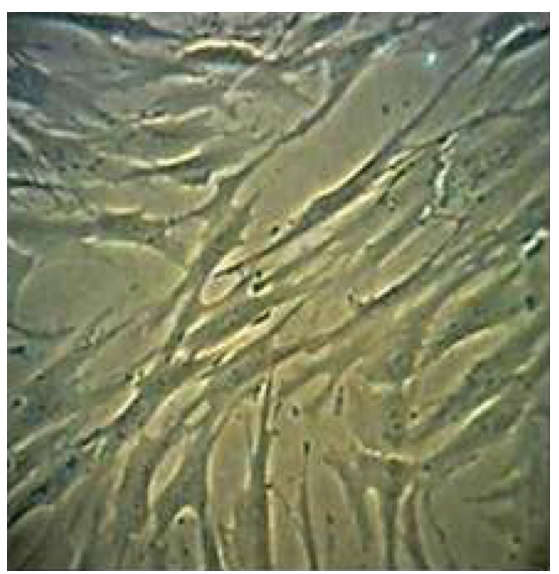

(a)

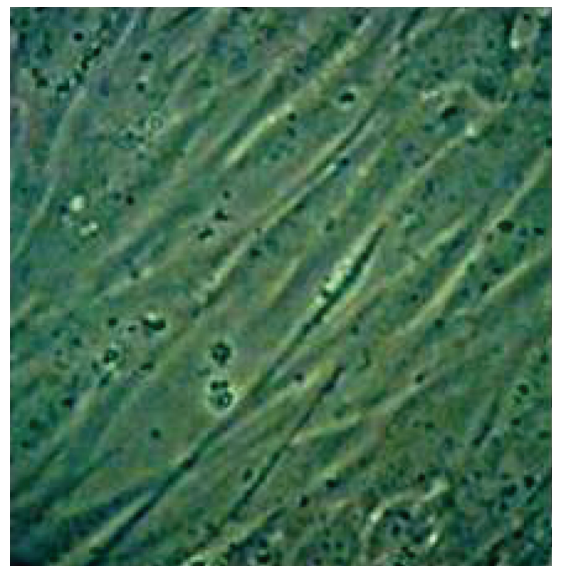

(d)

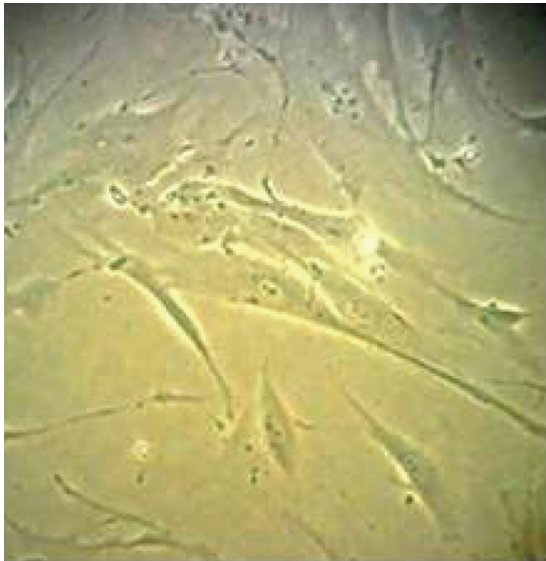

(b)

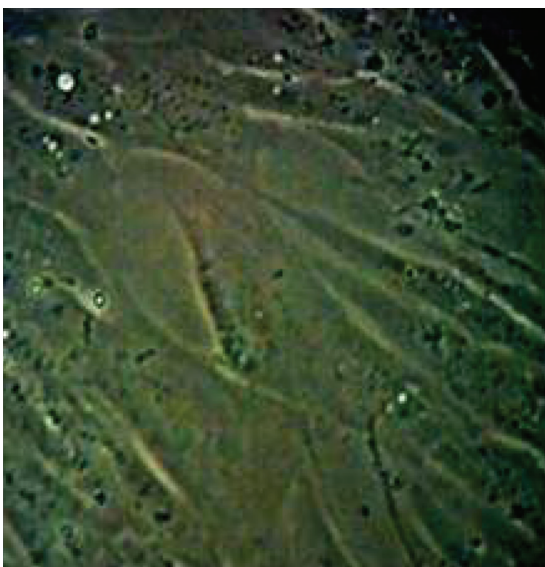

(e)

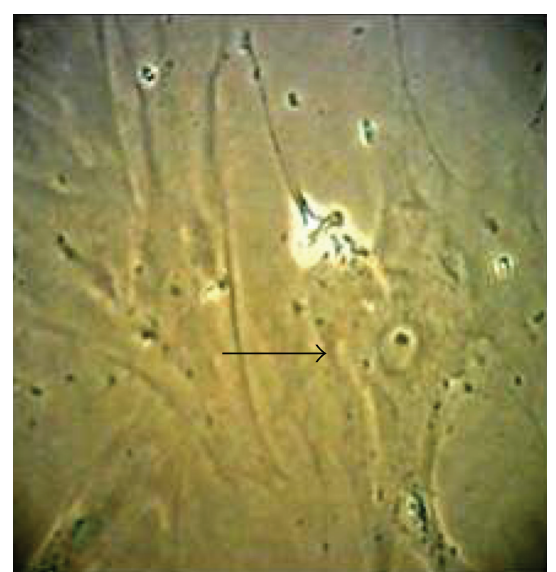

(c)

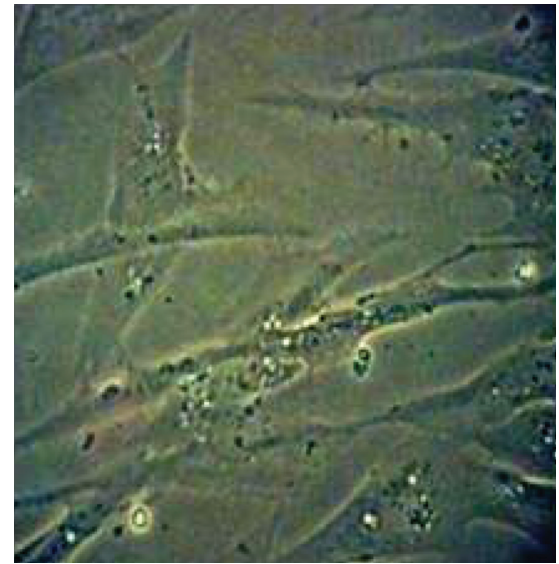

(f)

FIgURE 2: Morphological changes of HDFs in culture. Young (a), presenescent (b), and senescent (c) HDFs compared to TRF-treated HDFs (d)-(f). Senescent HDFs lost their original fibroblastic shape by acquiring a flattened morphology (indicated by arrow) with increased in size of nucleus and cells. The morphology of TRF-treated HDFs resembled that of young cells with more spindle-shaped cells present. Micrographs are shown at 200x magnification.

for all stages of cellular senescence of HDFs. In contrast, cell populations in $\mathrm{G}_{0} / \mathrm{G}_{1}$ phase decreased significantly $(P<.05)$ with TRF treatment in young, presenescent, and senescent HDFs (Figure 6).

\subsection{Effect of TRF Treatment on Telomere Length and} Telomerase Activity. Figure 7(a) shows the representative Southern blot analysis of HDFs at various passages with TRF treatment. Shortening of telomere length were observed with senescence of HDFs. Telomere length in senescent HDFs was significantly decreased compared to untreated young HDFs $(P<.05)$. Protective effects of TRF against telomere shortening was observed in senescent HDFs. Similar TRF treatment had no effect on telomere length in young HDFs (Figure 7(b)).

Figure 7(c) shows the representative PCR analysis for telomerase activity of HDFs at various passages with TRF treatment. Similarly, protection against loss of telomerase activity was observed in senescent HDFs. Treatment with TRF significantly increased the telomerase activity in senescent HDFs $(P<.05)$ whereby no effects was observed in young HDFs (Figure $7(\mathrm{~d})$ ).

\section{Discussion}

The present study evaluated the effects of tocotrienol-rich fraction (TRF) in possibly modulating cellular ageing in HDFs. Our results showed that when HDFs reached senescence, there were clear changes in cell morphology, decreased cell proliferation and increased senescence associated $\beta$ galactosidase activity. Typical morphology of senescent cells observed in this study has also been reported with multiple passages of cells [29]. Granular cytoplasmic and vacuoles accumulation are common features of senescent cells accounting for the large cells [16]. Senescent cells are also filled with large and numerous lysosomes that contain hydrolytic enzymes which function in ingesting and digesting organelles that are aged or damaged [30].

The biomarker SA- $\beta$-gal can distinguish senescent cells from quiescent cells. The increased SA- $\beta$-gal positive cells 


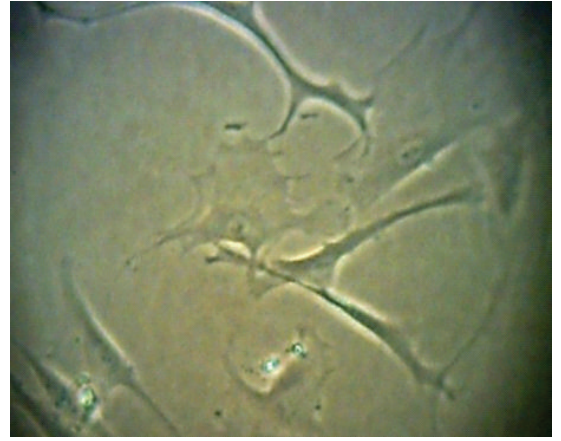

(a)

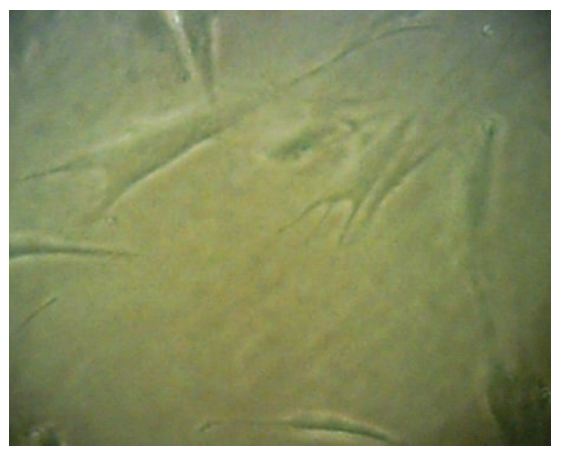

(d)

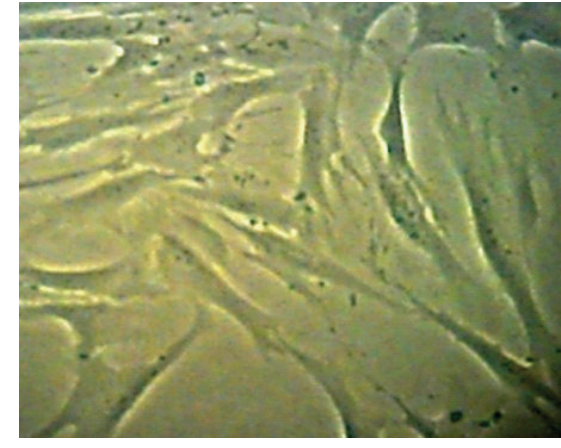

(b)

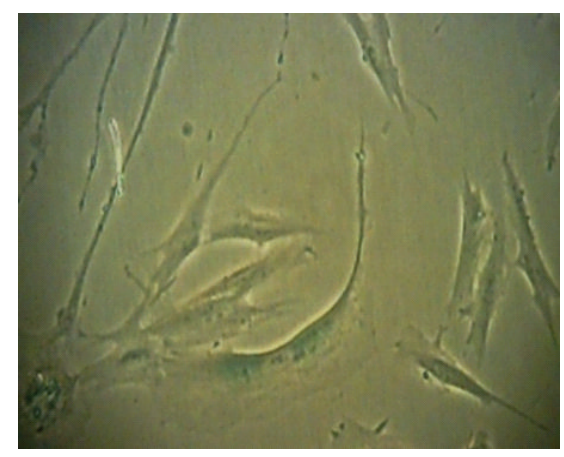

(e)

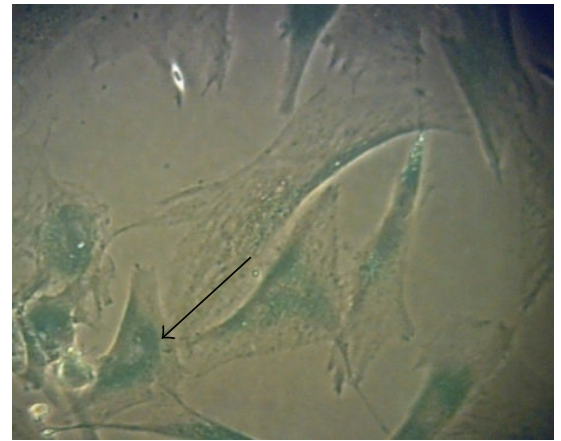

(c)

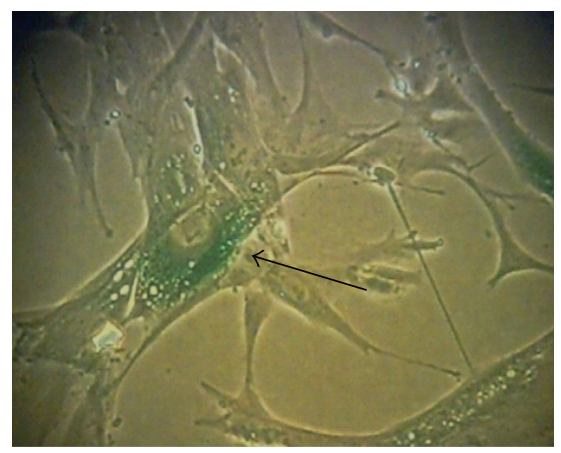

(f)

FIGURE 3: $\beta$-Galactosidase staining in young (a), presenescent (b) and senescent HDFs (c) compared to TRF-treated HDFs (d)-(f). Positive blue stain of SA- $\beta$-galactosidase appeared in senescent HDFs as indicated by arrow. Micrographs are shown at 200x magnification.

which was observed with senescence of HDFs can be attributed to increased in lysosomal content [31]. Increased autophagy may be associated with an increase in lysosomal mass and SA- $\beta$-gal in in vitro ageing [32]. In addition, it is possible to find a correlation between the increase in SA- $\beta$-gal and appearance of the senescent morphotypes.

Increase in SA- $\beta$-gal activity in senescent $\mathrm{HDF}$ and stress-induced premature senescence (SIPS) is an irreversible process upon subculture, suggesting that cellular ageing results in irreversible nonmitotic growth [33]. However, incubation with TRF was shown to decrease the percentage of cells positive for SA- $\beta$-gal suggesting a reversal of cellular ageing of HDFs. In addition, TRF-treated HDFs displayed a reduction in senescence characteristics. This effect is possibly due to the antioxidant property of TRF which consists of $\alpha$-tocopherols and all isomers of tocotrienols. Previous study has shown that tocotrienols have high antioxidant activity and that the uptake of tocotrienols from the culture medium by cultured cells was more efficient than tocopherols. Tocotrienol can penetrate rapidly through skin and efficiently combat oxidative stress [34].

Our data on cells viability study showed TRF treatment increased the percentage of viable cells with increasing concentrations of TRF. The percentage of viable cells was highest at the maximum concentration studied, that is, $0.5 \mathrm{mg} / \mathrm{mL}$ indicating TRF promoted cells propagation and viability in all stages of cellular ageing of HDFs.

Oxidative stress caused damage to DNA which increased significantly in senescent cells, especially in postmitotic tissues and the levels correlated with ageing and age-related diseases [35]. Tahara et al. reported that age-related increased in the levels of oxidative DNA base damage was a significant contributor to many age-related pathological diseases. If accumulation of damaged DNA exceeds its elimination by DNA repair mechanism, cellular senescence, or apoptosis takes place and contributes to the ageing process [36].

Comet assay allows visualization of damaged DNA in individual cells. Comparison of damaged DNA in different treatment groups of HDFs in the present study showed that total DNA damage was significantly increased in senescent cells while less damaged DNA was observed in young and presenescent HDFs. ROS caused chronic and persistent damage to DNA, causing double strand breaks that remain unrepaired which tend to accumulate in senescent cells indicating a possible cause of ageing in mammals [37]. Increased in ROS-induced DNA damage was reported to be correlated with cell cycle arrest [38]. Similarly, our data showed significant decreased in S phase cells and increased in damaged DNA in senescent HDFs indicating less cell proliferation and greater DNA damage as cells aged.

It is highly probable that protection against DNA damage with TRF treatment in senescent HDFs could be attributed to either prevention of oxidative stress-induced DNA damage or enhancement of DNA repair mechanism. Vitamin E, particularly $\alpha$-tocopherol, has been suggested to inhibit activation of endonuclease that can be triggered by intracellular oxidative stress and enhanced DNA repair by increasing the rate of removal of damaged DNA [18]. Previous study 


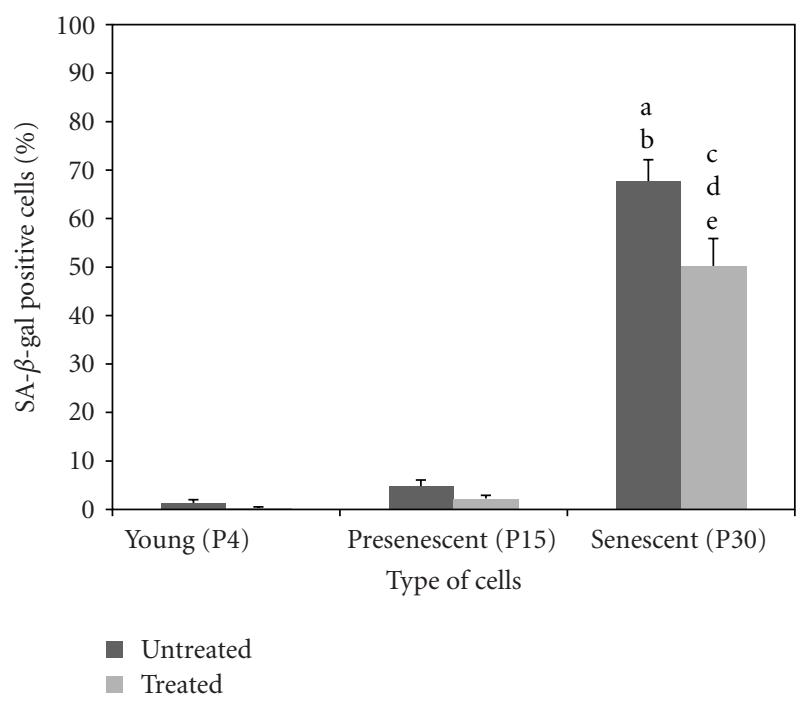

FIGURE 4: Quantitative analysis of positive $\beta$-galactosidase stained cells in HDFs during cellular ageing. The percentage of cells positive for SA- $\beta$-gal staining was significantly increased in senescent cells. Incubation of senescent cells with TRF significantly decreased the percentage of cells positive for SA- $\beta$-gal staining. ${ }^{a}$ Denotes $P<.05$ compared to untreated young HDFs, and ${ }^{\mathrm{b}} P<.05$ compared to untreated presenescent HDFs, ${ }^{\mathrm{c}} P<.05$ compared to untreated senescent HDFs, ${ }^{\mathrm{d}} P<.05$ compared to treated young HDFs, ${ }^{\mathrm{e}} P<$ .05 compared to treated presenescent HDFs. Data are presented as mean \pm SEM, $n=6$.

reported that vitamin $\mathrm{E}$ reduced $\mathrm{H}_{2} \mathrm{O}_{2}$-induced $\mathrm{HO}^{\bullet}$ generation and subsequent DNA base pair modification in human oral epithelial cells [16] besides decreasing $\mathrm{H}_{2} \mathrm{O}_{2}$-induced DNA strand breaks in human skin cell line VH10 [17].

Cellular senescence in response to DNA damage or degradation would make the cells's progeny nonviable and might indicate a decline in renewal capability of cells as they reach an irreversible growth arrest. Growth-arrested cells were predominantly seen in $G_{1}$ or $G_{2} / M$ phase. Our data showed no significant difference in $G_{0} / G_{1}$ or $G_{2} / M$ phase with cellular ageing of HDFs, while the $S$ phase cells decreased significantly. The reduction in S phase cells with senescence can be attributed to slow rate of proliferation as cells undergoing ageing. This process, however, was reduced by TRF treatment. The decreased and increased cells in $G_{0} / G_{1}$ phase and $S$ phase, respectively, were observed with TRF treatment at various stages of cellular ageing indicating inhibition of growth arrest and enhancement of cell replication. This observation indicated TRF was able to promote cell progression, and increased cells replicative capacity. Decreased level of total DNA damage and increased percentage of cells in S phase in TRF-treated senescent cells indicated a potential protective role of TRF against DNA strand breaks and cell cycle arrest.

One of the mechanisms mediating the development of the senescent phenotype is telomere shortening. It has been clearly demonstrated that cell replication caused telomere shortening due to the inability of DNA polymerase to completely replicate the $3^{\prime}$-ends of lagging strands in the

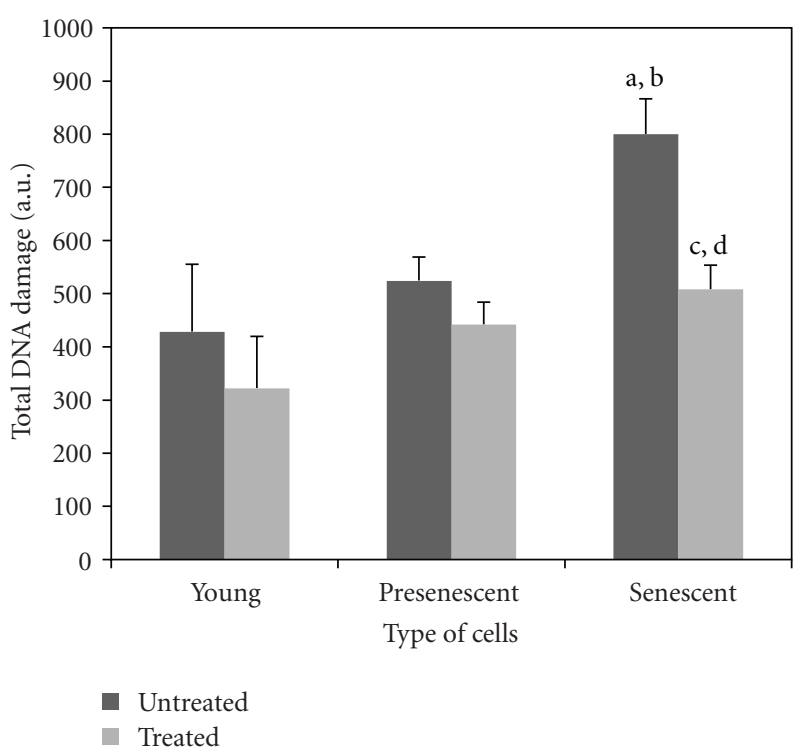

Figure 5: Comparison of total DNA damage at various stages of cellular ageing measured by Comet assay. Damaged DNA was higher in senescent HDFs which was decreased with TRF treatment. a Denotes $P<.05$ compared to untreated young HDFs, ${ }^{\mathrm{b}} P<.05$ compared to untreated presenescent HDFs, ${ }^{c} P<.05$ compared to untreated senescent HDFs, ${ }^{\mathrm{d}} P<.05$ compared to TRF-treated young HDFs. Data are presented as mean $\pm \mathrm{SD}, n=6$.

majority of normal human somatic cells which lack telomerase activity [39]. Our data in the present study suggested that both telomere shortening and decreased telomerase activity might be the contributing factors in cellular ageing. It has been reported that due to inherent limitations in the mechanics of DNA replication, telomeres shorten at each cell division, and in the absence of telomerase, when telomere shortening reaches a critical limit, cells are susceptible to chromosomal aberrations such as end-to-end fusion and aneuploidy. In such a situation, the cells cease to divide and reach replicative senescence [40]. Treatment with TRF, however, protected against telomere shortening in senescent HDFs with concomitant increased in telomerase activity. Our previous study had shown that both $\gamma$-tocotrienol and $\alpha$-tocopherol protected against oxidative stress-induced telomere shortening in HDFs derived from differently aged individuals. The restoration of telomerase activity induced by $\alpha$-tocopherol caused significant increased in telomere length especially in skin fibroblast obtained from old donor $[26,41]$.

In summary, TRF treatment exerted better protection in senescent HDFs when compared to young and presenescent HDFs. Possibly higher requirement for antioxidants is indicated in senescent HDFs as the uptake of TRF and its utilization in senescent HDFs is enhanced for protection against ROS related damage. Similar protective effects may not be required for young and presenescent HDFs.

Therefore, we concluded that tocotrienol-rich fraction delays or prevents cellular ageing particularly in senescent HDFs as shown by the elongated telomere length, decreased 

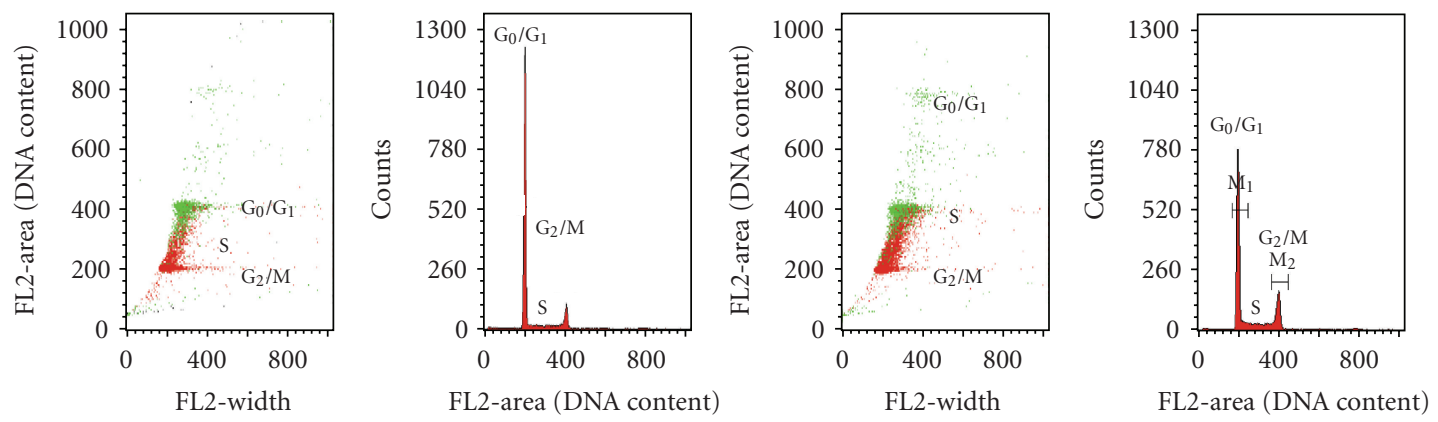

Young HDFs (untreated)
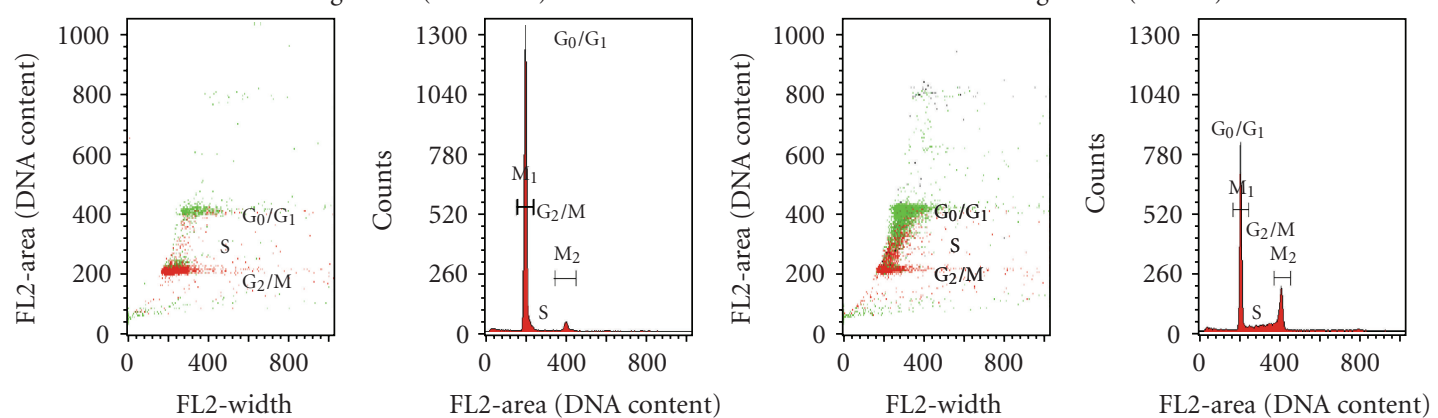

Presenescent HDFs (untreated)
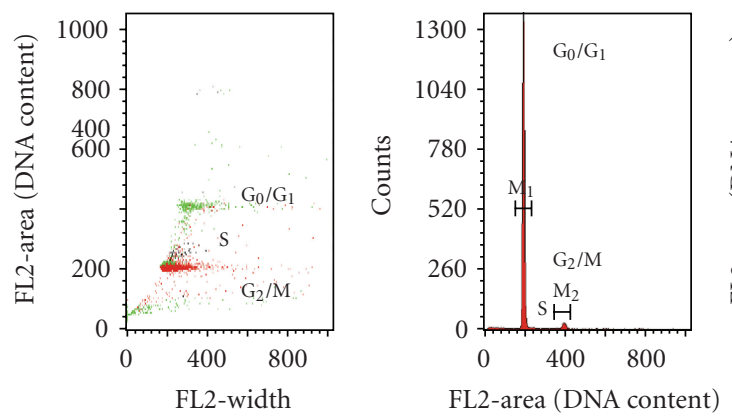

Senescent HDFs (untreated)

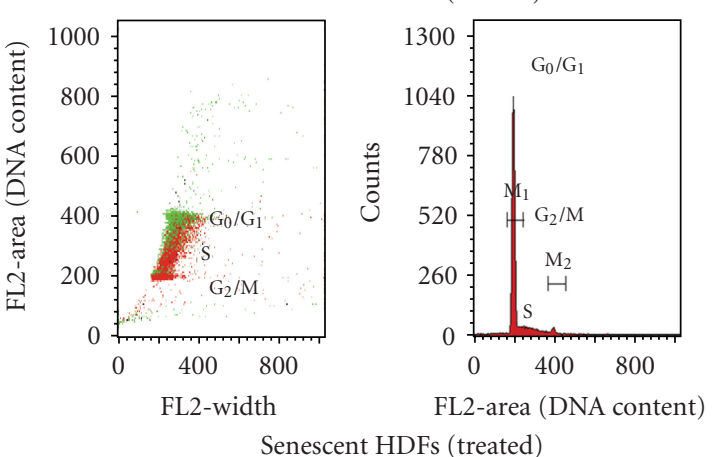

(a)
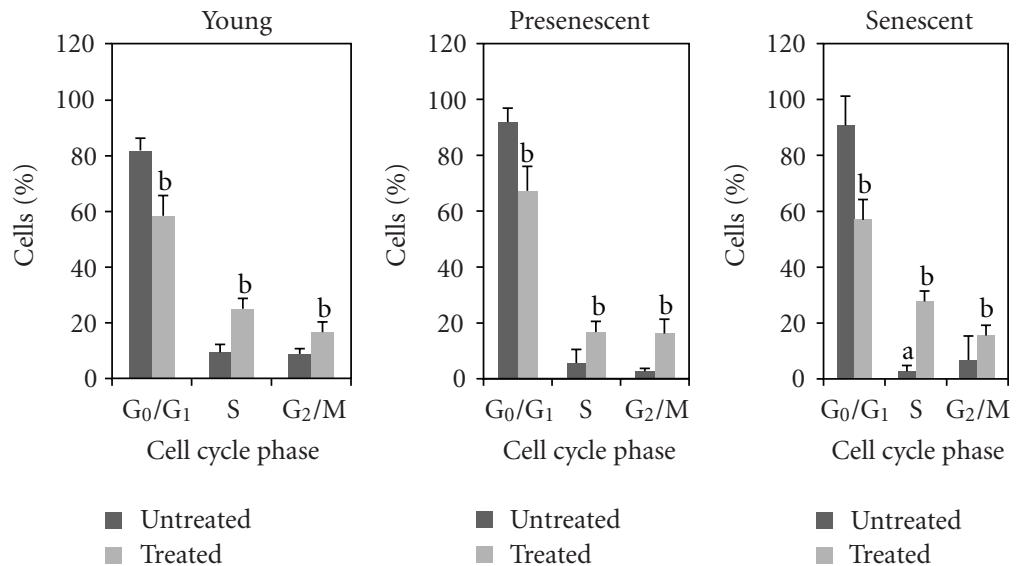

(b)

Figure 6: Analysis of cell cycle progression. Flow cytometric analysis of cell cycle progression in young, presenescent, and senescent HDFs (a). Quantitative analysis of cell cycle progression in untreated and TRF-treated HDFs at various stages of cellular ageing (b). Cell population in the $S$ phase was lower in senescent HDFs. Treatment with TRF significantly increased cells in $S$ phase and $G_{2} / M$ phase for all stages of cellular ageing of HDFs. In contrast, cell populations in $\mathrm{G}_{0} / \mathrm{G}_{1}$ phase decreased significantly with TRF treatment. ${ }^{\mathrm{a}}$ Denotes $P<.05$ compared to $\mathrm{S}$ phase of untreated young HDFs, ${ }^{\mathrm{b}} \mathrm{P}<.05$ compared to untreated HDFs. Data are presented as mean $\pm \mathrm{SD}, n=6$. 


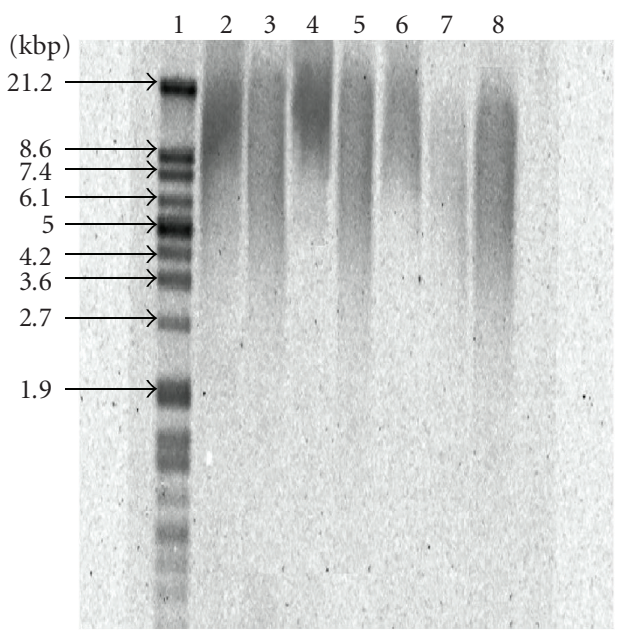

(a)

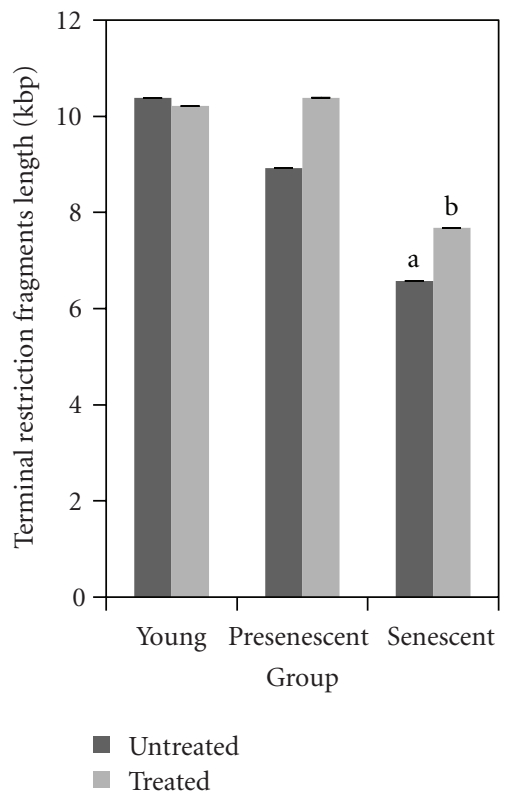

(b)
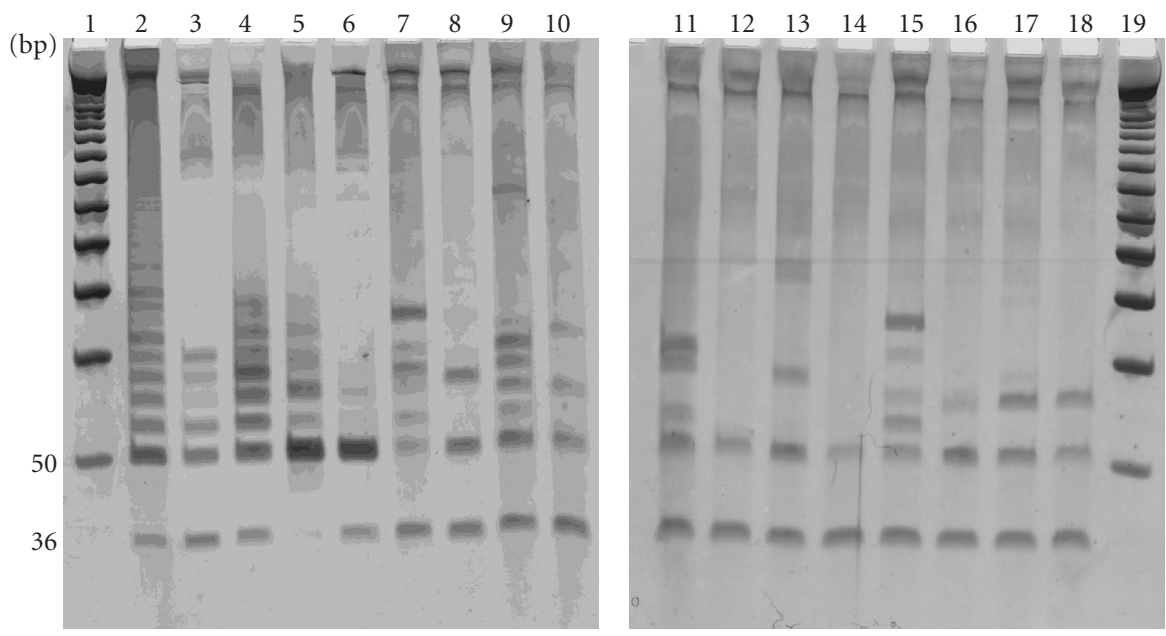

(c)

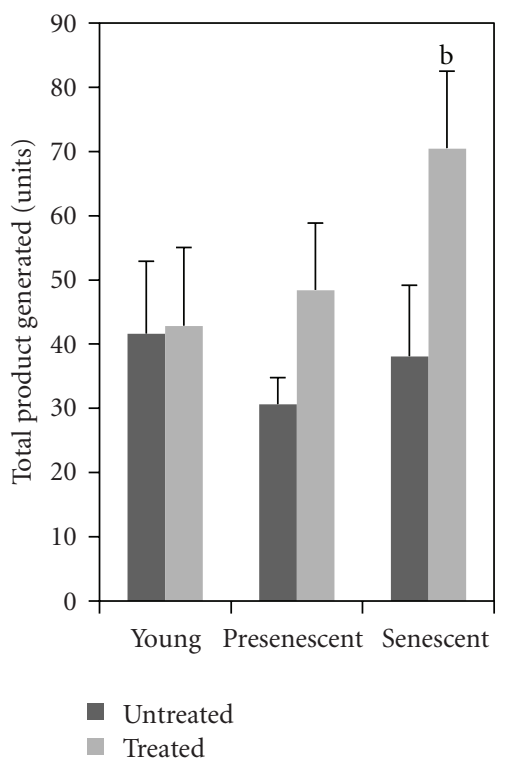

(d)

FIGURE 7: Effects of tocotrienol-rich fraction (TRF) on telomere length and telomerase activity. Representative Southern blot analysis of young, presenescent and senescent HDFs. Telomeric DNA is shown as wide smears in all lanes. Lane 1: molecular weight marker, lane 2: positive control DNA, lane 3: untreated young HDFs, lane 4: TRF-treated young HDFs, lane 5: untreated presenescent HDFs, lane 6: TRF-treated presenescent HDFs, lane 7: untreated senescent HDFs, lane 8: TRF-treated senescent HDFs (a). Telomere length (Terminal Restriction Fragments) of young, presenescent and senescent HDFs. Shortening of telomere length was observed with senescence of HDFs.

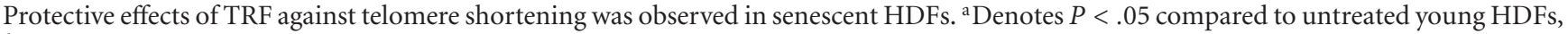
${ }^{\mathrm{b}} P<.05$ compared to untreated senescent HDFs. Data are presented as mean $\pm \mathrm{SEM}, n=6$ (b). Representative PCR analysis for telomerase activity of young, presenescent and senescent HDFs. Lane 1: molecular weight marker, lane 2: positive control, lane 3: positive control (heat treated), lane 4: TSR8 $(1 \mu \mathrm{L})$, lane 5: TSR8 $(2 \mu \mathrm{L})$, lane 6: negative control, lane 7: untreated young HDFs, lane 8: untreated young HDFs (heat treated), lane 9: TRF-treated young HDFs, lane 10: TRF-treated young HDFs (heat treated), lane 11: untreated presenescent HDFs, lane 12: untreated presenescent HDFs (heat treated), lane 13: TRF-treated presenescent HDFs, lane 14: TRF-treated presenescent HDFs (heat treated), lane 15: untreated senescent HDFs, lane 16: untreated senescent HDFs (heat treated), lane 17: TRF-treated senescent HDFs, lane 18: TRF-treated senescent HDFs (heat treated), lane 19: molecular weight marker (c). Telomerase activity (Total Product Generated, TPG) of young, presenescent and senescent HDFs. Treatment with TRF significantly increased the telomerase activity in senescent HDFs. ${ }^{\mathrm{a}}$ Denotes $P<.05$ compared to untreated senescent HDFs. Data is presented as mean \pm SEM, $n=6$ (d). 
levels of damaged DNA, and progression of cell cycle to $S$ phase besides increased cell propagation in all stages of cellular ageing of HDFs with TRF treatment.

\section{Acknowledgment}

This study was funded by the National University of Malaysia under research university Grant no. GUP-SK-07-21-043.

\section{References}

[1] L. Hayflick and P. S. Moorehead, "The serial cultivation of human diploid cell strains," Experimental Cell Research, vol. 25, no. 3, pp. 585-621, 1961.

[2] E. J. Yeo, Y. C. Hwang, C. M. Kang et al., "Senescencelike changes induced by hydroxyurea in human diploid fibroblasts," Experimental Gerontology, vol. 35, no. 5, pp. 553571,2000

[3] J. Campisi, "Cancer, aging and cellular senescence," In Vivo, vol. 14, no. 1, pp. 183-188, 2000.

[4] J. Duan, J. Duan, Z. Zhang, and T. Tong, "Irreversible cellular senescence induced by prolonged exposure to $\mathrm{H}_{2} \mathrm{O}_{2}$ involves DNA-damage-and-repair genes and telomere shortening," International Journal of Biochemistry and Cell Biology, vol. 37, no. 7, pp. 1407-1420, 2005.

[5] T. Finkel, "Oxidant signals and oxidative stress," Current Opinion in Cell Biology, vol. 15, no. 2, pp. 247-254, 2003.

[6] M. Wagner, B. Hampel, D. Bernhard, M. Hala, W. Zwerschke, and P. Jansen-Dürr, "Replicative senescence of human endothelial cells in vitro involves G1 arrest, polyploidization and senescence-associated apoptosis," Experimental Gerontology, vol. 36, no. 8, pp. 1327-1347, 2001.

[7] G. P. Dimri, X. Lee, G. Basile et al., "A biomarker that identifies senescent human cells in culture and in aging skin in vivo," Proceedings of the National Academy of Sciences of the United States of America, vol. 92, no. 20, pp. 9363-9367, 1995.

[8] K. Matuoka, K. Y. Chen, and T. Takenawa, "A positive role of phosphatidylinositol 3-kinase in aging phenotype expression in cultured human diploid fibroblasts," Archives of Gerontology and Geriatrics, vol. 36, no. 3, pp. 203-219, 2003.

[9] C.-S. Lim, "Cellular senescence, cancer, and organismal aging: a paradigm shift," Biochemical and Biophysical Research Communications, vol. 344, no. 1, pp. 1-2, 2006.

[10] J. Bartek and J. Lukas, "Mammalian G1- and S-phase checkpoints in response to DNA damage," Current Opinion in Cell Biology, vol. 13, no. 6, pp. 738-747, 2001.

[11] T. von Zglinicki, A. Bürkle, and T. B. L. Kirkwood, "Stress, DNA damage and ageing - an integrative approach," Experimental Gerontology, vol. 36, no. 7, pp. 1049-1062, 2001.

[12] T. von Zglinicki, R. Pilger, and N. Sitte, "Accumulation of single-strand breaks is the major cause of telomere shortening in human fibroblasts," Free Radical Biology and Medicine, vol. 28, no. 1, pp. 64-74, 2000.

[13] A. Smogorzewska and T. de Lange, "Regulation of telomerase by telomeric proteins," Annual Review of Biochemistry, vol. 73, pp. 177-208, 2004.

[14] M. P. Mattson, "Gene-diet interactions in brain aging and neurodegenerative disorders," Annals of Internal Medicine, vol. 139, no. 5, pp. 441-444, 2003.

[15] V. M. Factor, D. Laskowska, M. R. Jensen, J. T. Woitach, N. C. Popescu, and S. S. Thorgeirsson, "Vitamin E reduces chromosomal damage and inhibits hepatic tumor formation in a transgenic mouse model," Proceedings of the National Academy of Sciences of the United States of America, vol. 97, no. 5, pp. 2196-2201, 2000.

[16] G. A. Royack, M. P. Nguyen, D. C. Tong, M. Poot, and D. Oda, "Response of human oral epithelial cells to oxidative damage and the effect of vitamin E," Oral Oncology, vol. 36, no. 1, pp. 37-41, 2000.

[17] D. Slameňová, E. Horváthová, B. Košíková, L. Ružeková, and J. Lábaj, "Detection of lignin biopolymer- and vitamin E-stimulated reduction of DNA strand breaks in $\mathrm{H}_{2} \mathrm{O}_{2}$ and MNNG-treated mammalian cells by the comet assay," Nutrition and Cancer, vol. 33, no. 1, pp. 88-94, 1999.

[18] M. Konopacka, M. Widel, and J. Rzeszowska-Wolny, "Modifying effect of vitamins C, E and beta-carotene against gammaray-induced DNA damage in mouse cells," Mutation Research, vol. 417, no. 2-3, pp. 85-94, 1998.

[19] J. M. Zingg, "Modulation of signal transduction by vitamin E," Molecular Aspects of Medicine, vol. 28, no. 5-6, pp. 481-506, 2007.

[20] S. Schaffer, W. E. Müller, and G. P. Eckert, "Tocotrienols: constitutional effects in aging and disease," Journal of Nutrition, vol. 135, no. 2, pp. 151-154, 2005.

[21] W. L. Stone and A. Papas, "Tocopherols, tocotrienols, and vitamin E," in Lipids for Functional Foods and Nutraceuticals, F. D. Gunstone, Ed., pp. 53-72, PJ Barnes \& Associates, Bridgewater, UK, 2003.

[22] K. Sundram and A. Gapor, "Vitamin E from Palm Oil. Its extraction and nutritional properties," Lipid Technology, vol. 4, pp. 137-141, 1992.

[23] C. K. Sen, S. Khanna, and S. Roy, "Tocotrienols: vitamin E beyond tocopherols," Life Sciences, vol. 78, no. 18, pp. 20882098, 2006.

[24] H. Adachi and N. Ishii, "Effects of tocotrienols on life span and protein carbonylation in Caenorhabditis elegans," The Journals of Gerontology Series A, vol. 55, no. 6, pp. B280-B285, 2000.

[25] F. Nachbar and H. C. Korting, "The role of vitamin E in normal and damaged skin," Journal of Molecular Medicine, vol. 73, no. 1, pp. 7-17, 1995.

[26] S. Makpol, A. Zainuddin, N. A. Rahim, Y. A. Yusof, and W. Z. Ngah, "Alpha-tocopherol modulates hydrogen peroxideinduced DNA damage and telomere shortening of human skin fibroblasts derived from differently aged individuals," Planta Medica, vol. 76, no. 9, pp. 869-875, 2010.

[27] N. P. Singh, R. E. Stephens, and E. L. Schneider, "Modifications of alkaline microgel electrophoresis for sensitive detection of DNA damage," International Journal of Radiation Biology, vol. 66, no. 1, pp. 23-28, 1994.

[28] P. R. Heaton, R. Ransley, C. J. Charlton et al., "Application of single-cell gel electrophoresis (comet) assay for assessing levels of DNA damage in canine and feline leukocytes," Journal of Nutrition, vol. 132, no. 6, supplement 1, pp. 1598S-1603S, 2002.

[29] O. Toussaint, E. E. Medrano, and T. von Zglinicki, "Cellular and molecular mechanisms of stress-induced premature senescence (SIPS) of human diploid fibroblasts and melanocytes," Experimental Gerontology, vol. 35, no. 8, pp. 927-945, 2000.

[30] E. Bergamini, G. Cavallini, A. Donati, and Z. Gori, “The role of autophagy in aging: its essential part in the anti-aging mechanism of caloric restriction," Annals of the New York Academy of Sciences, vol. 1114, pp. 69-78, 2007. 
[31] D. J. Kurz, S. Decary, Y. Hong, and J. D. Erusalimsky, "Senescence-associated $\beta$-galactosidase reflects an increase in lysosomal mass during replicative ageing of human endothelial cells," Journal of Cell Science, vol. 113, no. 20, pp. 3613$3622,2000$.

[32] L.-M. Gerland, S. Peyrol, C. Lallemand, R. Branche, J.-P. Magaud, and M. Ffrench, "Association of increased autophagic inclusions labeled for $\beta$-galactosidase with fibroblastic aging," Experimental Gerontology, vol. 38, no. 8, pp. 887-895, 2003.

[33] N. C. Yang and M. L. Hu, "The limitations and validities of senescence associated- $\beta$ - galactosidase activity as an aging marker for human foreskin fibroblast Hs68 cells," Experimental Gerontology, vol. 40, no. 10, pp. 813-819, 2005.

[34] L. Packer, S. U. Weber, and G. Rimbach, "Molecular aspects of $\alpha$-tocotrienol antioxidant action and cell signalling," Journal of Nutrition, vol. 131, no. 2, 2001.

[35] J. W. Baynes, "The Maillard hypothesis on aging: time to focus on DNA," Annals of the New York Academy of Sciences, vol. 959, pp. 360-367, 2002.

[36] S. Tahara, M. Matsuo, and T. Kaneko, "Age-related changes in oxidative damage to lipids and DNA in rat skin," Mechanisms of Ageing and Development, vol. 122, no. 4, pp. 415-426, 2001.

[37] O. A. Sedelnikova, I. Horikawa, D. B. Zimonjic, N. C. Popescu, W. M. Bonner, and J. C. Barrett, "Senescing human cells and ageing mice accumulate DNA lesions with unrepairable double-strand breaks," Nature Cell Biology, vol. 6, no. 2, pp. 168-170, 2004.

[38] L. Migliore and F. Coppedè, "Genetic and environmental factors in cancer and neurodegenerative diseases," Mutation Research, vol. 512, no. 2-3, pp. 135-153, 2002.

[39] M. A. Rubio, A. R. Davalos, and J. Campisi, “Telomere length mediates the effects of telomerase on the cellular response to genotoxic stress," Experimental Cell Research, vol. 298, no. 1, pp. 17-27, 2004.

[40] N. Gupta, R. Taneja, A. Pandey, M. Mukesh, H. Singh, and S. C. Gupta, "Replicative senescence, telomere shortening and cell proliferation rate in Gaddi goat's skin fibroblast cell line," Cell Biology International, vol. 31, no. 10, pp. 1257-1264, 2007.

[41] S. Makpol, A. Z. Abidin, K. Sairin, M. Mazlan, G. M. Top, and W. Z. W. Ngah, " $\gamma$-tocotrienol prevents oxidative stressinduced telomere shortening in human fibroblasts derived from different aged individuals," Oxidative Medicine and Cellular Longevity, vol. 3, no. 1, pp. 35-43, 2010. 

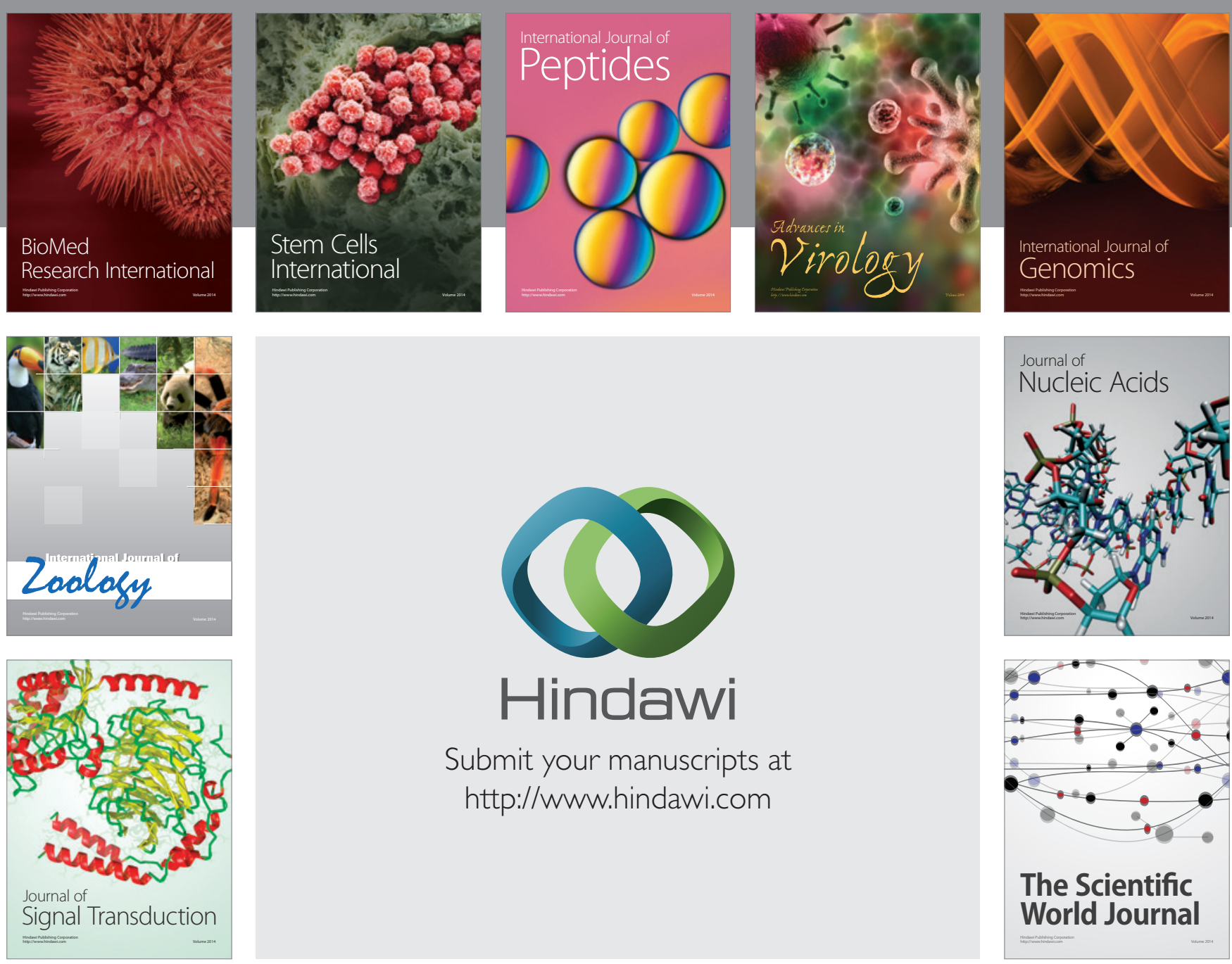

Submit your manuscripts at

http://www.hindawi.com
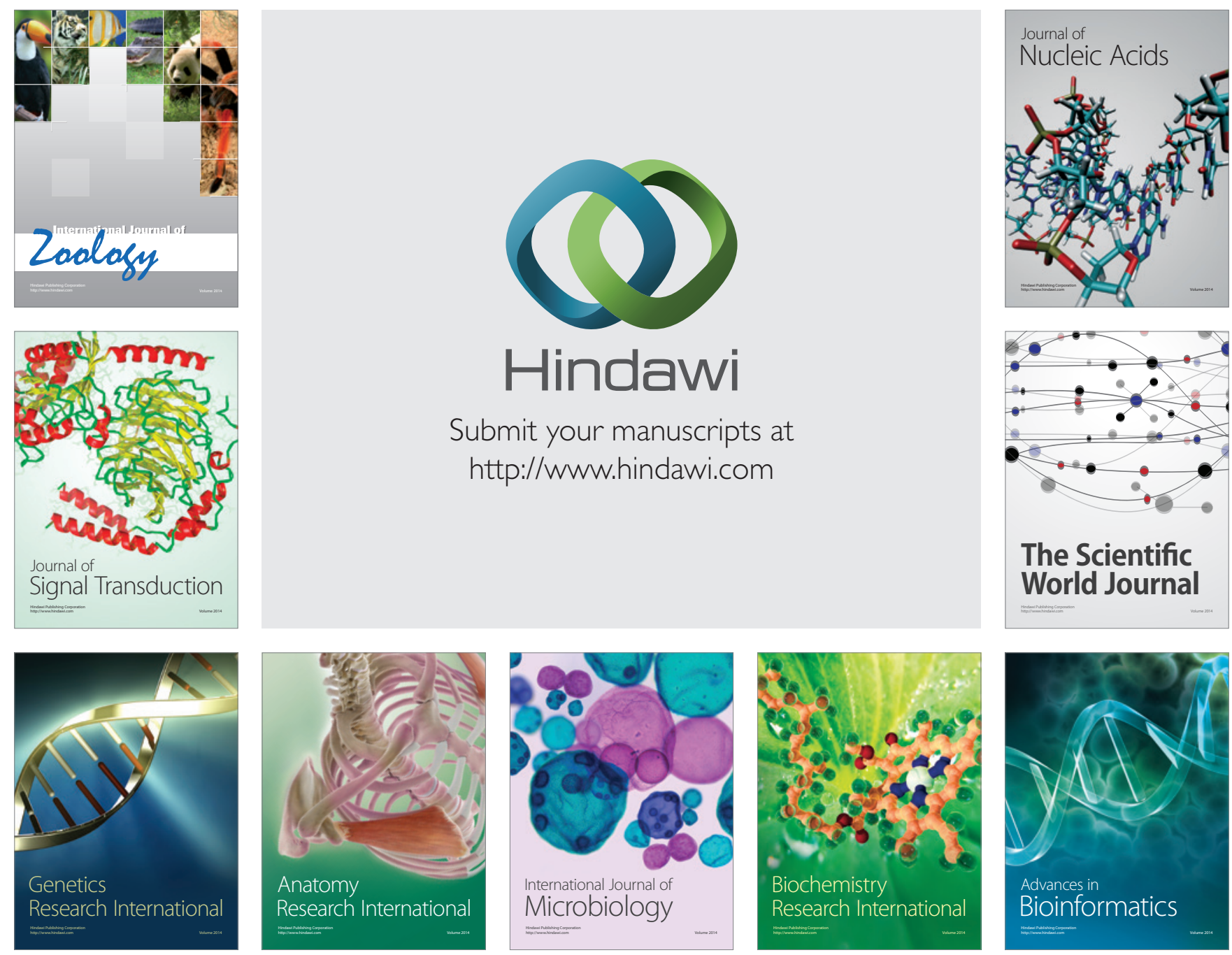

The Scientific World Journal
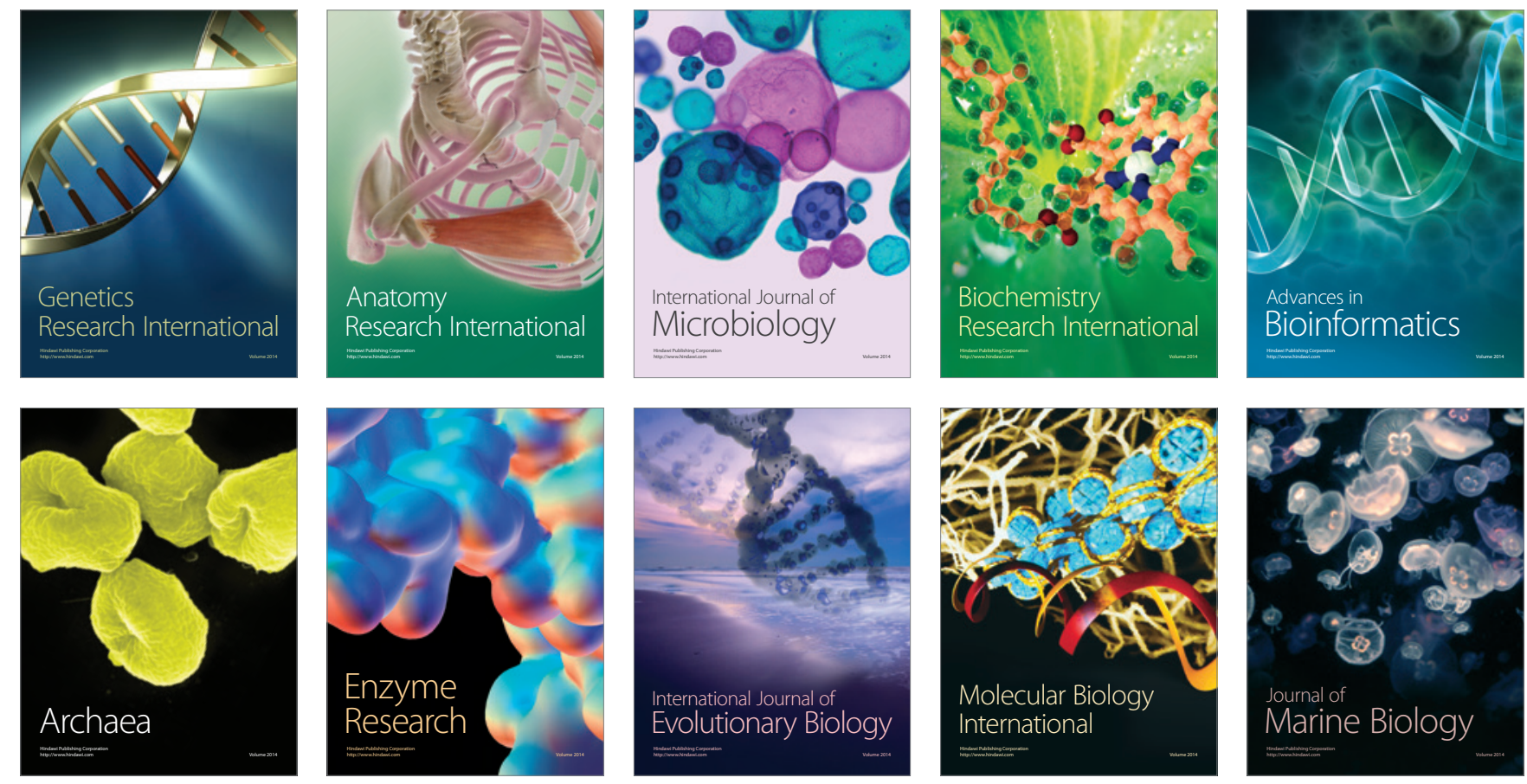